\title{
Evaluasi Kesesuaian RKP dan RKPD 34 Provinsi terkait DAK Fisik Penugasan Bidang Lingkungan Hidup dan Kehutanan 2019
}

\author{
Andi Setyo Pambudi ${ }^{1}$ \\ Kementerian Perencanaan Pembangunan Nasional/Bappenas - Indonesia
}

\begin{abstract}
Abstraksi
Development of the Environment and Forestry (LHK) is essentially carried out in order to increase the carrying capacity of land and the environment. In practice, national development in this field involves the central and regional governments in accordance with their authority and funding capacity. One of the efforts to reduce fiscal inequality and in the context of accelerating national development in the LHK sector, the central government is allocating the Special Allocation Fund (DAK) Physical Assignment. This transfer fund is needed because until 2019, efforts to improve the quality of the environment and the carrying capacity of watersheds and lakes are still not in line with national expectations. This paper attempts to analyze the planning and implementation of the DAK Physical Assignment 2019 from the evaluation of regional development perspective. This study uses a mixed method by using both secondary numerical data (planning documents, achievements and other relevant documents) and primers. Data collection was obtained through FGDs and questionnaires at sample locations. The gap analysis method is used to find gaps in centralregional planning and assess the appropriateness of the allocation of funding received by the province with the development targets outlined in the 2019 RKP. The results of the study found that the suitability of the RKP and RKPD 34 provinces in 2019 with the DAK Physical Assignment 2019 for the Environment and Forestry (LHK) is 22.3\%. Allocation of Special Allocation Fund (DAK) Physical Assignment in the Field of Environment and Forestry 2019 does not yet reflect the watershed and lake priority areas as stipulated in Presidential Regulation No. 141/2018. There are still many Provinces that are in the watershed and priority lake but the budget allocation for Special Allocation Fund (DAK) Physical Assignment in the Field of Environment and Forestry is small. Based on the results of filling out the questionnaire, $71 \%$ of DAK has been effective in achieving goals / targets, while the remaining $29 \%$ is still not optimal. In its implementation, several obstacles were encountered that required further recommendations.
\end{abstract}

Keywords: Special Allocation Fund, Environment, Forestry, Evaluation

${ }^{1}$ Andi Setyo Pambudi adalah Kepala Sub Direktorat Pemantauan, Evaluasi dan Pengendalian Pembangunan Daerah Wilayah IV, Kementerian PPN/Bappenas. E-mail: andi.pambudi@bappenas.go.id 


\title{
Evaluasi Kesesuaian RKP dan RKPD 34 Provinsi terkait DAK Fisik Penugasan Bidang Lingkungan Hidup dan Kehutanan 2019
}

\author{
Andi Setyo Pambudi
}

\section{Pendahuluan}

Sebagaimana diketahui, era reformasi adalah bentuk penolakan terhadap sistem sentralisasi yang telah gagal dalam berbagai aspek untuk mewujudkan kesejahteraan sosial bagi seluruh rakyat Indonesia (Brodjonegoro, 2006). Argumen yang mendukung desentralisasi adalah peningkatan penyampaian layanan publik dan pemahaman yang lebih baik tentang preferensi fiskal dan kebutuhan lokal melalui pemerintah daerah dibandingkan dengan pemerintah pusat (Oates, 1999)

Sistem sentralisasi dianggap selalu melakukan unifikasi kekuasaan politik dan ekonomi pada tangan pemerintah pusat, maka sebaliknya desentralisasi mengajukan gagasan tentang pembagian kekuasaan politik, ekonomi, dan wewenang administrasi antara pemerintah pusat dan daerah (Hidayat, 2005).

Dari aspek ekonomi, sistem sentralisasi berpegang teguh pada konsep pusat pertumbuhan. Konsep ini pertama kali diperkenalkan oleh Fancois Perroux penganut aliran ekonomi keseimbangan umum. Ia menyatakan bahwa teori pusat pertumbuhan didefinisikan sebagai suatu gugus industri yang mampu membangkitkan pertumbuhan ekonomi yang dinamis dan mempunyai kaitan yang kuat melalui hubungan input-output di sekitar leading industry (Setiadi 2009). Paradigma pusat pertumbuhan ekonomi dikritik oleh berbagai pihak karena dalam realitasnya trickle down effect tidak terwujud, yang terjadi malah sebaliknya, yaitu trickle up effect (Kuncoro, 2004). Pembagian "kue kesejahteraan” bukan dari atas ke bawah, tetapi kekayaan daerah mengalir ke pusat. Ini adalah bentuk dari hasil praktek teori ekonomi neo-klasik yang melahirkan ketimpangan pendapatan.

Pengalaman di banyak negara berkembang menunjukkan bahwa tingginya ketimpangan menghambat pertumbuhan ekonomi (Bonet, 2006). Pada awalnya meskipun pertumbuhan ekonomi tinggi, tetapi kemudian terjerembap dalam krisis yang dalam. Bukan saja ekonomi, melainkan juga sosial-politik. Perekonomian yang berhasil menjadi maju pada umumnya ketimpangan pendapatannya relatif rendah, yang berarti perkembangan ekonomi melibatkan peran serta luas masyarakat. Keseimbangan merupakan konsep dasar dalam teori ekonomi. Tanpa keseimbangan, konsep ekonomi menjadi berantakan. Dalam dinamikanya, perekonomian berkembang dari suatu keseimbangan yang rendah kepada keseimbangan yang lebih tinggi. Dalam praktiknya, keseimbangan menjadi penentu perkembangan kegiatan ekonomi. Tanpa keseimbangan, praktis tidak ada transaksi ekonomi karena keadaan menjadi tidak pasti, terutama berkaitan dengan harga sebagai penentu keseimbangan. Otonomi daerah adalah salah satu landasan demokratisasi yang memliki tujuan akhir mewujudkan kesejahteraan masyarakat (Hirawan, 2007).

Skema pembiayaan pembangunan nasional dalam bingkai otonomi daerah adalah sebuah kebutuhan yang mendasar (Oates, 1993). Salah satu skema yang memperhatikan kepentingan pemerintah pusat di daerah adalah dana transfer khusus. Dana Transfer Khusus 
adalah dana yang dialokasikan dalam Anggaran Pendapatan dan Belanja Negara kepada daerah dengan tujuan untuk membantu mendanai kegiatan khusus, baik fisik maupun nonfisik yang merupakan urusan daerah. Salah satu bentuk dana transfer tersebut adalah Dana Alokasi Khusus, baik fisik maupun non fisik. Dana Alokasi Khusus Fisik adalah dana yang bersumber dari pendapatan Anggaran Pendapatan dan Belanja Negara yang dialokasikan kepada daerah tertentu dengan tujuan untuk membantu mendanai kegiatan khusus yang merupakan Urusan Pemerintahan yang menjadi kewenangan Daerah dan sesuai dengan prioritas nasional.

Bidang LHK menjadi salah satu bidang pembangunan yang dibiayai dengan Dana Alokasi Khusus Fisik. Dalam konteks ini, penggunaan anggaran DAK untuk Bidang Lingkungan Hidup dan Kehutanan termasuk dalam sistem perencanaan pembangunan yang menunjang program prioritas nasional yang tertuang dalam dokumen Rencana Pembangunan Jangka Menengah Nasional (RPJMN) dan dirinci dalam Rencana Kerja Pemerintah (RKP). Sampai saat ini, upaya peningkatan kualitas lingkungan dan daya dukung DAS dan danau masih belum sesuai dengan yang diharapkan secara nasional. Sehubungan dengan itu, Pemerintah Daerah perlu memprioritaskan penyediaan prasarana dan sarana maupun pembangunan fisik terkait lingkungan hidup dan kehutanan dengan lebih tepat sasaran sesuai target-target nasional. Menu kegiatan dalam DAK fisik penugasan bidang ini relevan untuk mendukung beberapa target nasional yang meliputi : 1) pengurangan luas lahan kritis; 2) target pemulihan 15 DAS; 3) sipil teknis Konservasi Tanah dan Air (KTA); 4) industri yang memenuhi baku mutu emisi; 5) pengelolaan sampah; 6) restorasi gambut. Sasaran DAK Fisik Penugasan Sub Bidang LHK diantaranya adalah memulihkan kesehatan 15 Daerah Aliran Sungai Prioritas dan 15 Danau Prioritas.

Pasal 13 ayat 1 Peraturan Presiden (Perpres) No. 141 Tahun 2018 tentang Petunjuk Teknis DAK Fisik Tahun Anggaran 2019 menyatakan bahwa pemantauan dan evaluasi pengelolaan DAK Fisik di daerah dilaksanakan secara sendiri-sendiri atau bersama-sama oleh menteri/pimpinan lembaga, Menteri Keuangan, Menteri Perencanaan Pembangunan Nasional/Kepala Badan Perencanaan Pembangunan Nasional, dan Menteri Dalam Negeri. Pada Pasal 13 ayat 2 bagian c secara spesifik menyebutkan bahwa Menteri Perencanaan Pembangunan Nasional/Kepala Badan Perencanaan Pembangunan Nasional melakukan pemantauan dan evaluasi terhadap pencapaian keluaran (output), serta dampak dan manfaat pelaksanaan kegiatan setiap bidang DAK Fisik yang menjadi prioritas nasional. Implementasi DAK Fisik Bidang LHK menjadi suatu hal yang manarik diulas karena berkaitan dengan kualitas lingkungan hidup dan daya dukung DAS sebagai penyangga utama tercapainya prioritas-prioritas pembangunan lainnya.

\section{Bahan dan Metode}

Studi ini menggunakan pendekatan Mixed Method dengan penggunaan data-data numerik baik sekunder maupun primer. Dalam analisis kebijakan, pendekatan analisis isi digunakan melalui studi literatur baik teori yang relevan maupun kebijakan pada sektor DAK Fisik Penugasan khususnya Bidang LHK. Studi ini juga menggunakan analisis gap yang membuthkan data dokumen perencanaan tahunan (RKP) dan perencanaan daerah (RKPD 34 Provinsi). Analisis capaian menggunakan data capaian dari OM-SPAN Kementerian Keuangan. Pengumpulan data dilakukan melalui kunjungan lapangan dan pembagian kuisioner dengan mengambil sampel Provinsi Sumatera Utara. Kunjungan 
lapangan dilakukan dalam bentuk diskusi (Focused Groups Discussion), wawancara serta pengamatan langsung di lokasi pembangunan/ pelaksanaan kegiatan DAK.

\section{Sasaran dan Jenis Kegiatan DAK Fisik Penugasan Bidang LHK 2019}

Sasaran DAK Fisik Penugasan Sub Bidang LHK diantaranya adalah memulihkan kesehatan 15 Daerah Aliran Sungai Prioritas dan 15 Danau Prioritas. Pemerintah telah menetapkan 15 DAS dan 15 Danau Prioritas dalam RPJMN 2015-2019. 15 DAS Prioritas tersebut meliputi : DAS Asahan (Sumatera Utara), DAS Siak (Riau), DAS Musi (Sumatera Selatan), DAS Citarum (Jawa Barat), DAS Sekampung (Lampung), DAS Cisadane (Jawa Barat, Banten), DAS Ciliwung (Jawa Barat, DKI Jakarta), DAS Serayu (Jawa Tengah), DAS Bengawan Solo (Jawa Tengah), DAS Brantas (Jawa Timur), DAS Kapuas (Kalimantan Barat, Kalimantan Tengah), DAS Saddang (Sulawesi Barat, Sulawesi Tengah), DAS Jeneberang (Sulawesi Selatan), DAS Moyo (Nusa Tenggara Barat), DAS Limboto (Sulawesi Utara).

Disamping itu, 15 Danau Prioritas telah ditetapkan oleh Pemerintah untuk dipulihkan meliputi Danau Toba (Sumatera Utara), Danau Rawapening (Jawa Tengah), Danau Rawadanau (Banten), Danau Batur (Bali), Danau Kerinci (Jambi), Danau Singkarak (Sumatera Barat), Danau Poso (Sulawesi Tengah), Danau Cascade Mahakam (Kalimantan Timur), Danau Melintang dan Tondano (Sulawesi Utara), Danau Tempe-Danau Matano (Sulawesi Selatan), Danau Limboto (Gorontalo), Danau Sentarum (Kalimantan Barat), Danau Jempang (Kalimantan Timur) dan Danau Sentani (Papua).

Peraturan Presiden No. 72/2018 menetapkan 12 (dua belas) menu kegiatan dalam skema DAK Fisik Penugasan Bidang Lingkungan Hidup dan Kehutanan yang menunjang Program Prioritas Nasional yaitu 9 menu kegiatan untuk Sub Bidang Lingkungan Hidup dan 3 (tiga) menu kegiatan untuk Sub Bidang Kehutanan. Kedua belas menu kegiatan tersebut meliputi : 1) Pengelolaan Sampah serta Sarana Prasarana Pendukung; 2) Pengadaan Alat Angkut Sampah dump truck; 3) Pengadaan Alat Angkut Sampah arm roll; 4) Pengurangan dan Pengendalian Beban Pencemaran Air Limbah Cair melalui Instalasi Pengolahan Air Limbah Usaha Skala Kecil (IPAL USK); 5) Pengadaan Alat/Sistem Pemantauan Kualitas Air Secara Kontinyu, Otomatis, dan Online; 6) Pengadaan Peralatan Laboratorium untuk Uji Kualitas Air; 7) Pengadaan Sarana dan Prasarana Pengolahan Emas Non-Merkuri; 8) Pengadaan Peralatan Laboratorium untuk Uji Kualitas Merkuri; 9) Pengendalian Pencemaran Udara di Provinsi/Kabupaten/Kota Metropolitan, Besar, dan Ibukota Provinsi Rawan Karhutla (kebakaran Hutan dan Lahan); 10) Pengembangan Sarana dan Prasarana Usaha Ekonomi Produktif; 11) Rehabilitasi Hutan dan Lahan; 12) Pembangunan Sarana Prasarana Operasionalisasi KPH, Tahura dan Hutan Kota.

\section{Pembahasan}

\subsection{Analisis Kesesuaian Alokasi DAK Bidang LHK Provinsi dan Sararan RKP 2019}

Dalam RKP 2019, sektor Lingkungan Hidup dan Kehutanan (LHK) masuk dalam Prioritas Nasional 4 (PN 4) yaitu Pemantapan Ketahanan Energi, Pangan dan Sumber Daya Air serta Prioritas Nasional 1 (PN 1) yaitu Pembangunan Manusia melalui Pengurangan Kemiskinan dan Peningkatan Pelayanan Dasar. Prioritas Nasional 4 yang berkaitan erat dengan urusan Lingkungan Hidup dan Kehutanan ada dua Program Prioritas yaitu 1) Program Prioritas Peningkatan Kuantitas, Kualitas dan Aksesibilitas Sumber Daya Air; 2) 
Program Prioritas Peningkatan Daya Dukung Sumber Daya Alam dan Daya Tampung Lingkungan. Prioritas Nasional 1 yang erat kaitannya dengan urusan kehutanan yaitu Percepatan Pengurangan Kemiskinan.

Tabel 1. Dana Alokasi Khusus (DAK) Fisik Penugasan Bidang LHK Mendukung Kebijakan Bidang SDALH dalam RKP 2019

\begin{tabular}{c|l|l}
\hline No & Arah Kebijakan Bidang SDALH & \multicolumn{1}{|c}{$\begin{array}{l}\text { Intervensi melalui Kegiatan DAK Fisik } \\
\text { Penugasan Bidang LHK }\end{array}$} \\
\hline 1. & $\begin{array}{l}\text { Peningkatan tata kelola hutan } \\
\text { melalui pembentukan dan } \\
\text { operasional KPH }\end{array}$ & $\begin{array}{l}\text { Pembangunan sarana prasarana operasional } \\
\text { KPH melalui pembangunan resort KPH dan } \\
\text { sarana kendaraan roda dua untuk pengamanan } \\
\text { hutan }\end{array}$ \\
\hline 2. & $\begin{array}{l}\text { Peningkatkan kualitas lingkungan } \\
\text { hidup, melalui penurunan beban } \\
\text { pencemaran air, udara, dan lahan }\end{array}$ & $\begin{array}{l}\text { Pengendalian penggunaan merkuri pada } \\
\text { tambang emas rakyat melalui sarana } \\
\text { prasarana pengolahan emas non merkuri 6 } \\
\text { kegiatan }\end{array}$ \\
\hline 3. & $\begin{array}{l}\text { Peningkatkan kualitas lingkungan } \\
\text { hidup, melalui pengelolaan sampah } \\
\text { spesifik, serta pengolahan sampah } \\
\text { melalui bank sampah dan pusat } \\
\text { daur ulang sampah }\end{array}$ & $\begin{array}{l}\text { Pembangunan Bank Sampah kapasitas 1 ton/ } \\
\text { hari sejumlah 249 unit, dengan target } \\
\text { pengurangan timbunan sampah sebesar } \\
90.885 \text { ton/ tahun }\end{array}$ \\
\hline
\end{tabular}

Sumber: Diolah dari PerPres No 72 tahun 2018 dan PerPres No 141 tahun 2018

Tahun 2019, alokasi anggaran DAK Fisik Penugasan Sub Bidang LHK mencapai Rp530.200.000.000,00 dimana alokasi untuk Sub Bidang Lingkungan Hidup sebesar Rp225.500.000.000,00 dan Sub Bidang Kehutanan sebesar Rp304.700.000.000,00. Alokasi DAK Fisik Penugasan Sub Bidang Kehutanan tersebar di 33 Provinsi (tanpa DKI Jakarta) dengan alokasi terbesar berada di Provinsi Sumatera Barat sebesar Rp2 1.445.554.000,00 dan alokasi terkecil di Provinsi Kepulauan Riau sebesar Rp582.595.000,00. Sementara itu, Alokasi DAK Fisik Penugasan Sub Bidang Lingkungan Hidup tersebar di 33 Provinsi (kecuali DKI Jakarta) dimana alokasi terbesar di Provinsi Jawa Tengah sebesar Rp25.033.961.000,00 dan alokasi terkecil di Provinsi Maluku Utara sebesar Rp1.304.429.000,00. Jika dilihat dari sasaran, DAK Fisik Penugasan Sub Bidang Lingkungan Hidup memiliki salah satu sasaran wilayah adalah 15 DAS Prioritas dan 15 Danau Prioritas. 

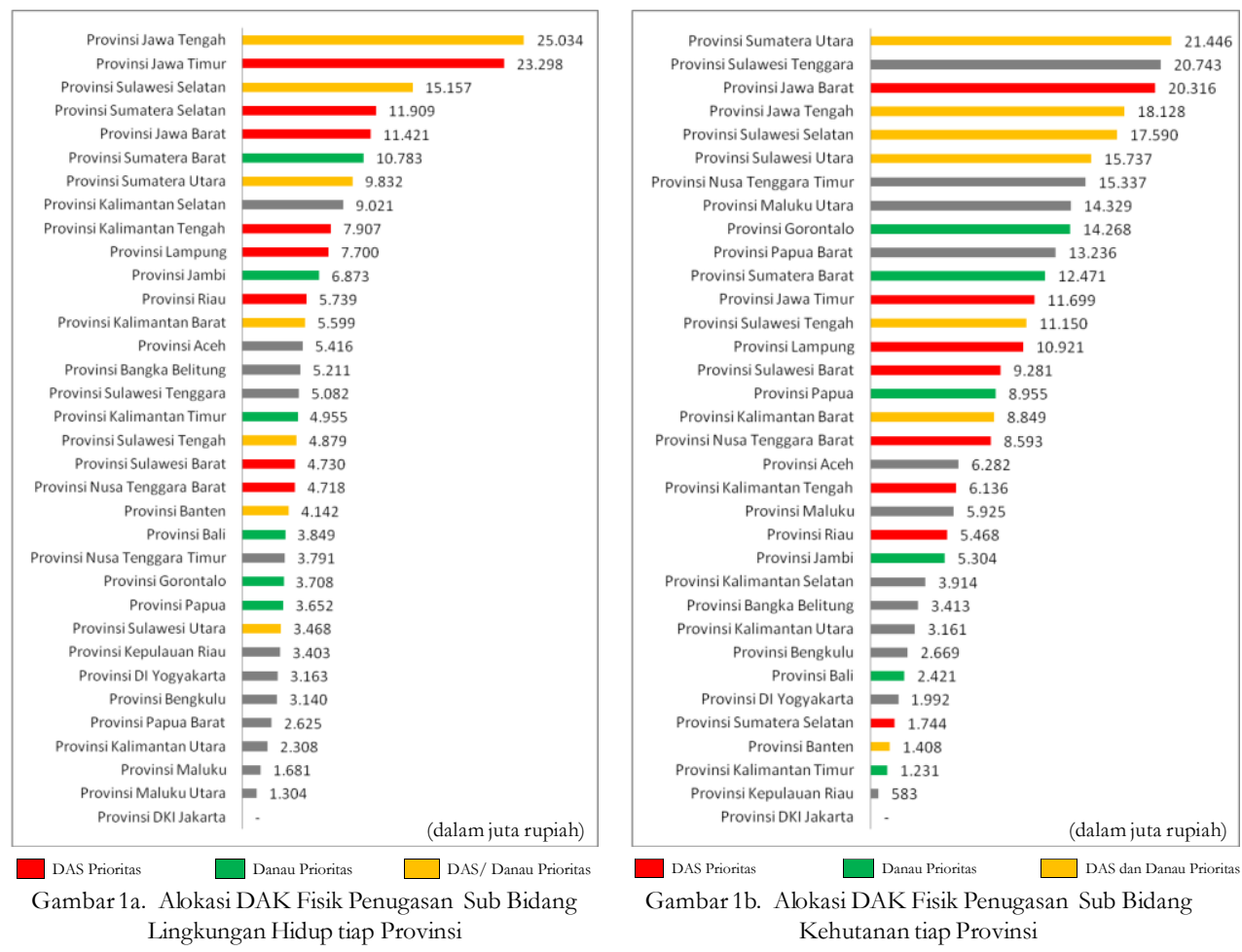

Gambar 1. Alokasi DAK Fisik Penugasan Bidang Lingkungan Hidup dan Kehutanan

Tahun 2019 tiap Provinsi

Sumber: Direktorat Otonomi Daerah, Bappenas, 2019

Alokasi DAK Fisik Penugasan Sub Bidang LH belum mencerminkan prioritas kewilayahan DAS dan Danau sesuai yang tertuang dalam Peraturan Presiden No 141/2018. Masih banyak Provinsi yang merupakan wilayah DAS dan Danau Prioritas namun alokasi anggaran DAK Fisik Penugasan Sub Bidang LH kecil, seperti pada Provinsi Sulawesi Utara, Banten, Sulawesi Tenggara dan Kalimantan Barat. Provinsi Kalimantan Selatan yang bukan merupakan wilayah DAS dan Danau Prioritas memiliki alokasi anggaran DAK Fisik Penugasan Sub Bidang LH terbesar kedelapan dari 33 provinsi, begitu juga dengan DAK Sub Bidang Kehutanan, alokasi DAK Fisik Penugasan Sub Bidang Kehutanan belum mencerminkan prioritas kewilayahan DAS dan Danau yang tertuang dalam Peraturan Presiden No 141/2018.

Hasil analisis menunjukkan bahwa masih banyak provinsi yang merupakan wilayah DAS dan Danau Prioritas namun alokasi anggaran DAK Fisik Penugasan Sub Bidang Kehutanannya kecil, seperti pada Provinsi Kalimantan Timur, Banten, Sumatera Selatan, Bali, Jambi, Riau, Kalimantan Tengah. Provinsi Sulawesi Tenggara yang bukan merupakan wilayah DAS dan Danau Prioritas memiliki alokasi anggaran DAK Fisik Penugasan Sub Bidang Kehutanan ke dua terbesar dari 33 Provinsi yaitu sebesar Rp20.742.903.000,00. Berdasarkan data tersebut, arah kebijakan yang tertuang dalam Peraturan Presiden 141/2018 dengan kebijakan alokasi anggaran DAK belum sinkron sehingga alokasi DAK 
Fisik Penugasan Sub Bidang LHK belum optimal memulihkan kesehatan 15 DAS dan 15 Danau Prioritas Nasional.

\subsection{Analisis Kesenjangan (gap) RKP dan RKPD terkait DAK Fisik Penugasan LHK 2019}

Berdasarkan hasil analisis kesenjangan perencanaan (RKP-RKPD), Provinsi Sulawesi Barat dan Sulawesi Tengah tidak menetapkan menu kegiatan Bidang Lingkungan Hidup dan Kehutanan ke dalam RKPD. Provinsi Jawa Barat telah menetapkan 8 menu kegiatan yang selaras dengan RKP atau sebesar 66 persen telah sesuai dengan RKP. Hasil analisis juga menunjukkan bahwa pada 31 provinsi lainnya hanya menetapkan program Bidang Lingkungan Hidup dan Kehutanan (yang didanai dari DAK) ke dalam RKPD-nya berkisar 1-5 menu kegiatan atau kesesuaian dengan RKP sebesar 8,3 persen sampai dengan 41,6 persen (lihat Gambar 2).

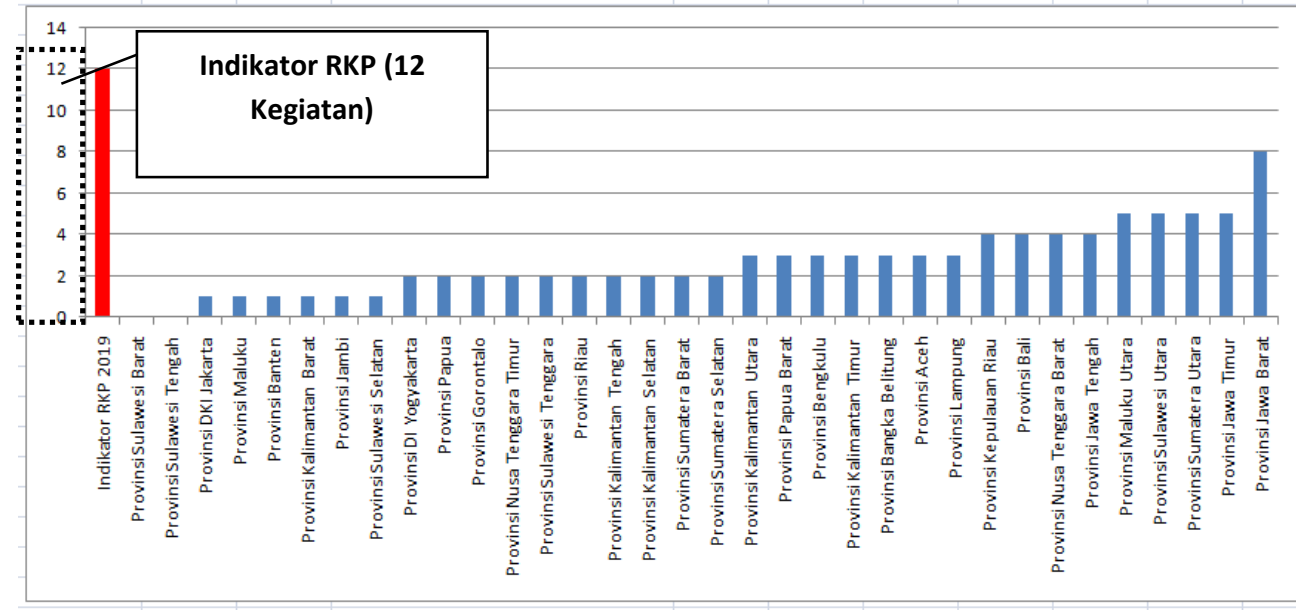

Jumlah Menu Kegiatan dalam RKP Jumlah Menu Kegiatan dalam RKPD

Gambar 2. Kesesuaian RKPD dengan RKP tahun 2019 terkait DAK Fisik Penugasan Bidang Lingkungan Hidup dan Kehutanan

Sumber: Diolah dari RKP 2019 dan RKPD 34 Provinsi Tahun 2019

\subsection{Studi Kasus : DAK Fisik Penugasan Bidang LHK 2019 Provinsi Sumatera Utara}

Uji petik analisis lapangan DAK Fisik Penugasan LHK Tahun 2019 dilakukan di Provinsi Sumatera Utara. Pemerintah Provinsi Sumatera Utara memiliki rencana kerja pada tahun 2019 yang dituangkan ke dalam Peraturan Gubernur No 30 tahun 2018 tentang Rencana Kerja Pemerintah Daerah Provinsi Sumatera Utara tahun 2019. Rencana Kerja Pemerintah Daerah (RKPD) Provinsi Sumatera Utara memiliki tema "Peningkatan Pembangunan untuk Mendorong Penciptaan Struktur Ekonomi yang Tangguh dalam Rangka Mewujudkan Sumatera Utara yang Mandiri, Makmur dan Berkeadilan” dengan fokus prioritas pembangunan daerah meliputi: 1) Peningkatan pembangunan Sumber Daya Manusia (SDM) dan pengurangan kemiskinan melalui pemenuhan pelayanan dasar masyarakat; 2) Pengurangan kesenjangan antar wilayah melalui peningkatan pembangunan 
infrastruktur, penguatan konektivitas dan kemaritiman; 3) Pertumbuhan ekonomi inklusif berkelanjutan melalui pengembangan pertanian, industri pengolahan, pariwisata, jasa dan perdagangan; 4) Peningkatan ketahanan pangan, energi dan sumber daya air serta mitigasi bencana; dan 5) Peningkatan reformasi birokrasi, tatakelola pemerintahan, penegakan hukum dan pencegahan korupsi.

Rencana Kerja Pemerintah Daerah (RKPD) Pemerintah Provinsi Sumatera Utara tahun 2019 telah mendukung agenda pembangunan nasional yang tertuang dalam RKP 2019. Berdasarkan hasil sinkronisasi, RKPD Provinsi Sumatera Utara tahun 2019 telah sesuai mendukung Prioritas Nasional (PN).

Tabel 2. Sinkronisasi Prioritas Nasional dan Provinsi tahun 2019

\begin{tabular}{l|l}
\hline \multicolumn{1}{c|}{\begin{tabular}{c}
\multicolumn{1}{c}{ RKP 2019} \\
Prioritas Nasional)
\end{tabular}} & \multicolumn{1}{c}{$\begin{array}{c}\text { RKPD Sumatera Utara 2019 } \\
\text { (Prioritas Pembangunan Provinsi) }\end{array}$} \\
\hline $\begin{array}{l}\text { Pembangunan manusia melalui } \\
\text { pengurangan kemiskinan dan } \\
\text { peningkatan pelayanan dasar }\end{array}$ & $\begin{array}{l}\text { Peningkatan pembangunan SDM dan } \\
\text { pengurangan kemiskinan melalui } \\
\text { pemenuhan pelayanan dasar masyarakat }\end{array}$ \\
\hline $\begin{array}{l}\text { Pengurangan kesenjangan antar wilayah } \\
\text { melalui penguatan konektivitas dan } \\
\text { kemaritiman }\end{array}$ & $\begin{array}{l}\text { Pengurangan kesenjangan antar wilayah } \\
\text { melalui peningkatan pembangunan } \\
\text { infrastruktur, penguatan konektivitas dan } \\
\text { kemaritiman }\end{array}$ \\
\hline $\begin{array}{l}\text { Peningkatan nilai tambah ekonomi dan } \\
\text { penciptaan lapangan kerja melalui } \\
\text { pertanian, industri, pariwisata dan jasa } \\
\text { produktif lainnya }\end{array}$ & $\begin{array}{l}\text { Pertumbuhan ekonomi inklusif } \\
\text { berkelanjutan melalui pengembangan } \\
\text { pertanian, industri pengolahan, pariwisata, } \\
\text { jasa dan perdagangan }\end{array}$ \\
\hline $\begin{array}{l}\text { Pemantapan ketahanan energi, pangan } \\
\text { dan sumber daya air }\end{array}$ & $\begin{array}{l}\text { Peningkatan ketahanan pangan, energi dan } \\
\text { sumber daya air serta mitigasi bencana }\end{array}$ \\
\hline $\begin{array}{l}\text { Stabilitas keamanan nasional dan } \\
\text { kesuksesan pemilihan umum }\end{array}$ & $\begin{array}{l}\text { Peningkatan reformasi birokrasi, tatakelola } \\
\text { pemerintahan, penegakan hukum dan } \\
\text { pencegahan korupsi }\end{array}$ \\
\hline \multicolumn{1}{c}{ Sumban }
\end{tabular}

Sumber: Diolah dari RKP 2019 dan RKPD Provinsi Sumatera Utara tahun 2019

Dalam mendukung PN Pemantapan ketahanan energi, pangan dan sumber daya air, RKPD Sumatera Utara Tahun 2019 telah menetapkan tema program pembangunan yaitu peningkatan kualitas lingkungan hidup dan pengendalian pencemaran dan perusakan lingkungan hidup. 
Tabel 3. Sinkronisasi Program Pusat-Daerah dalam Konteks DAK Penugasan Bidang Lingkungan Hidup dan Kehutanan

\begin{tabular}{|c|c|c|}
\hline $\begin{array}{l}\text { DAK Penugasan Sub Bidang LHK } \\
\text { yang tertuang dalam RKP } 2019\end{array}$ & $\begin{array}{l}\text { Program dan Kegiatan } \\
\text { dalam Perpres No } 141 \\
\text { tahun } 2018 \text { tentang } \\
\text { Petunjuk Teknis DAK }\end{array}$ & $\begin{array}{c}\text { Program } \\
\text { Pembangunan } \\
\text { Provinsi dalam } \\
\text { RKPD Sumatera } \\
\text { Utara tahun } 2019\end{array}$ \\
\hline $\begin{array}{l}\text { 1. Pengelolaan Sampah serta } \\
\text { Sarana Prasarana Pendukung } \\
\text { 2. Pengadaan Alat Angkut Sampah } \\
\text { dump truck } \\
\text { 3. Pengadaan Alat Angkut } \\
\text { Sampah arm roll } \\
\text { 4. Pengurangan dan Pengendalian } \\
\text { Beban Pencemaran Air Limbah } \\
\text { Cair melalui Instalasi } \\
\text { Pengelolaan Air Limbah (IPAL) } \\
\text { Usaha Skala Kecil (USK) } \\
\text { 5. Pengadaan Alat/Sistem } \\
\text { Pemantauan Kualitas Air Secara } \\
\text { Kontinyu, Otomatis, dan Online } \\
\text { 6. Pengadaan Peralatan } \\
\text { Laboratorium untuk Uji Kualitas } \\
\text { Air } \\
\text { 7. Pengadaan Sarana dan } \\
\text { Prasarana Pengolahan Emas } \\
\text { Non-Merkuri } \\
\text { 8. Pengadaan Peralatan } \\
\text { Laboratorium untuk Uji Kualitas } \\
\text { Merkuri } \\
\text { 9. Pengendalian Pencemaran } \\
\text { Udara di } \\
\text { Provinsi/Kabupaten/Kota } \\
\text { Metropolitan, Besar, dan } \\
\text { Ibukota Provinsi Rawan } \\
\text { Kebkaran Hutan dan Lahan } \\
\text { (KARHUTLA) }\end{array}$ & $\begin{array}{l}\text { Sub Bidang Lingkungan } \\
\text { Hidup untuk Kabupaten/ } \\
\text { Kota } \\
\text { 1. Pengurangan dan } \\
\text { pengendalian beban } \\
\text { pencemaran dari limbah } \\
\text { cair sebesar 30 persen } \\
\text { pada 15 Daerah Aliran } \\
\text { Sungai (DAS) prioritas/ } \\
\text { 15 Danau prioritas } \\
\text { 2. Pengelolaan sampah } \\
\text { Sub Bidang Lingkungan } \\
\text { Hidup untuk Provinsi } \\
\text { 1. Penyediaan sistem } \\
\text { pematauan kualitas air } \\
\text { secara kontinyu, } \\
\text { otomatis, dan online } \\
\text { 2. Penyediaan peralatan } \\
\text { laboratorium untuk uji } \\
\text { kualitas air dan merkuri }\end{array}$ & $\begin{array}{ll}\text { 1. } & \text { Peningkatan } \\
\text { indeks kualitas } \\
\text { lingkungan } \\
\text { hidup } \\
\text { 2. Penurunan } \\
\text { emisi efek gas } \\
\text { rumah kaca } \\
\text { 3. Perlindungan } \\
\text { dan konservasi } \\
\text { Sumber Daya } \\
\text { Alam (SDA) } \\
\text { 4. Peningkatan } \\
\text { kualitas dan } \\
\text { akses informasi } \\
\text { SDA dan } \\
\text { lingkungan } \\
\text { hidup }\end{array}$ \\
\hline $\begin{array}{l}\text { Sub Bidang Kehutanan } \\
\text { 1. Pengembangan Sarana dan } \\
\text { Prasarana Usaha Ekonomi } \\
\text { Produktif } \\
\text { 2. Rehabilitasi Hutan dan Lahan } \\
\text { 3. Pembangunan Sarana Prasarana } \\
\text { Operasionalisasi Kesatuan } \\
\text { Pengelolaan Hutan (KPH), } \\
\text { Taman Hutan Raya (Tahura) } \\
\text { dan Hutan Kota } \\
\end{array}$ & \begin{tabular}{|l} 
Sub Bidang Kehutanan \\
1. Pengembangan sarana \\
dan prasarana usaha \\
ekonomi produktif \\
2. Rehabilitasi hutan dan \\
lahan, berupa : \\
pemeliharaan tanaman, \\
pembuatan tanaman, \\
pembuatan dam \\
penahan, pembuatan \\
\end{tabular} & Tidak tersedia \\
\hline
\end{tabular}




\begin{tabular}{|c|c|c|}
\hline $\begin{array}{l}\text { DAK Penugasan Sub Bidang LHK } \\
\text { yang tertuang dalam RKP } 2019\end{array}$ & $\begin{array}{c}\text { Program dan Kegiatan } \\
\text { dalam Perpres No } 141 \\
\text { tahun } 2018 \text { tentang } \\
\text { Petunjuk Teknis DAK }\end{array}$ & $\begin{array}{c}\text { Program } \\
\text { Pembangunan } \\
\text { Provinsi dalam } \\
\text { RKPD Sumatera } \\
\text { Utara tahun } 2019\end{array}$ \\
\hline & $\begin{array}{l}\text { gully plug dan } \\
\text { pembangunan sumur } \\
\text { resapan } \\
\text { 3. Pembangunan sarana } \\
\text { prasarana operasional } \\
\text { KPH, Tahura, dan hutan } \\
\text { kota ,berupa: } \\
\text { pembangunan resor } \\
\text { KPH, pembangunan } \\
\text { sarana prasarana wisata, } \\
\text { dan penyediaan } \\
\text { kendaraan roda-2 untuk } \\
\text { pengamanan } \\
\text { KPH/Tahura }\end{array}$ & \\
\hline
\end{tabular}

Sumber: Diolah dari RKP 2019, RKPD Sumatera Utara tahun 2019, Perpres 141/2018

Dalam konteks DAK Fisik Penugasan Sub Bidang Lingkungan Hidup, RKPD Provinsi Sumatera Utara tahun 2019 telah relevan dengan RKP tahun 2019. Rencana Kerja Pemerintah Daerah (RKPD) Provinsi Sumatera Utara telah mengalokasikan tema program yang dengan menu DAK Fisik Penugasan Sub Bidang Lingkungan Hidup meliputi : 1) Peningkatan Indeks Kualitas Lingkungan Hidup (IKLH) ; 2) Penurunan emisi efek gas rumah kaca; 3) Perlindungan dan konservasi Sumber Daya Alam (SDA); 4) Peningkatan kualitas dan akses informasi SDA dan lingkungan hidup, namun Rencana Kerja Pemerintah Daerah (RKPD) Provinsi Sumatera Utara belum mengalokasikan tema kegiatan yang relevan dengan menu DAK Fisik Penugasan Sub Bidang Kehutanan.

Berdasarkan hasil kunjungan lapangan, ada beberapa lokasi kegiatan tidak sesuai dengan sasaran yang telah tertuang dalam Perpres No 72/2018 dan Perpres No 141/2018, misalnya di Kabupaten Tebing Tinggi, lokasi sarana prasana pembangunan pengelolaan sampah tidak dibangun di lokasi satuan wilayah DAS Asahan dan bagian dari hulu Danau Toba sehingga sarana yang dibangun belum mendukung pengelolaan sampah untuk memulihkan kesehatan DAS Asahan dan juga kesehatan Danau Toba. Berdasarkan hasil kuesioner, sebagian pemerintah daerah berpendapat bahwa menu DAK Fisik Penugasan Sub Bidang LHK telah sesuai dengan kebutuhan daerah (50 persen), namun sebagian lainnya berpendapat bahwa menu DAK belum sesuai dengan kebutuhan mereka (50 persen).

Bagi Pemerintah Daerah, anggaran DAK Fisik Penugasan Sub Bidang LH tidak cukup memenuhi kebutuhan daerah untuk mengelola sampah dan pengelolaan lingkungan lainnya dengan alasan meliputi : 1) Kebutuhan bank sampah dan sarana prasarana persampahan (kasus di Kota Tebing Tinggi) lebih besar dibandingkan dana DAK yang diberikan; 2) Prasarana dan sarana di daerah belum lengkap dan tidak memenuhi syarat pengelolaan lingkungan; 3) Belum tercukupi pemenuhan sarana dan prasarana untuk pengelolaan lingkungan (kasus Kabupaten Simalungun); 4) Kabupaten Serdang Bedagai 
memerlukan banyak fasilitas, sarana dan prasarana untuk laboratorium dan pengelolaan persampahan. Menu dalam DAK Fisik Penugasan Sub Bidang LH tidak sepenuhnya selaras dengan kebutuhan pemerintah daerah. Seperti yang dialami oleh Kabupaten Tobasa sarana pendukung dasar seperti tong sampah, bak sampah, kontainer sampah tidak lagi ada dalam menu DAK tahun 2019, padahal Kabupaten Tobasa masih memerlukan prasarana tersebut. Kriteria teknis dan administrasi untuk mendapatkan alokasi dana DAK belum sepenuhnya ideal. Ada beberapa kabupaten/kota tidak mendapatkan alokasi DAK meskipun telah memiliki persyaratan administrasi, misalnya Kota Tebing Tinggi tidak mendapatkan alokasi DAK tahun 2020 meskipun telah memenuhi salah satu persyaratan yaitu telah menerima Piala Adipura dan memiliki Kebijakan Strategi Daerah (Jakstrada).

Berdasarkan hasil pengisian kuesioner, pemerintah daerah berpendapat bahwa 71 persen DAK sudah efektif untuk mencapai tujuan/sasaran, sedangkan 29 persen sisanya masih belum optimal. Bagi daerah, terbatasnya jumlah anggaran juga menyebabkan efektivitas DAK rendah. Terbatasnya anggaran menyebabkan pemerintah daerah harus menetapkan skala prioritas, sehingga tidak semua tujuan bisa tercapai. Pada tahun 2019, menu DAK Fisik Penugasan Sub Bidang Kehutanan tidak menyediakan kegiatan pembangunan dam pengendali tetapi hanya menyediakan kegiatan pembangunan dam Penahan. Saat ini, untuk meredam sedimentasi sungai, dam pengendali lebih baik dibandingkan dengan dam penahan. Atas dasar itu, kegiatan tahun 2019 pada aspek sipil teknis kurang optimal untuk memenuhi sasaran untuk memperbaiki fungsi dan kesehatan DAS prioritas.

Pada pelaksanaan RKP dalam konteks DAK Fisik Penugasan Bidang Lingkungan Hidup dan Kehutanan beberapa temuan ringkas dan kendala dapat dilihat pada Tabel 4.

Tabel 4. Temuan Ringkas dan Kendala Pelaksanaan RKP DAK Fisik Penugasan Bidang Lingkungan Hidup dan Kehutanan

\begin{tabular}{|c|c|}
\hline Temuan Permasalahan & Kendala \\
\hline $\begin{array}{l}\text { Sebagian Bappeda Provinsi tidak } \\
\text { mengetahui perkembangan kegiatan } \\
\text { yang bersumber dari APBN khususnya } \\
\text { DAK Fisik Penugasan Sub Bidang } \\
\text { Lingkungan Hidup }\end{array}$ & $\begin{array}{l}\text { Kurangnya koordinasi Pemerintah Provinsi } \\
\text { dengan Kementerian LHK dan Pemerintah } \\
\text { Kabupaten/Kota dalam implementasi DAK } \\
\text { Fisik Penugasan Sub Bidang Lingkungan } \\
\text { Hidup }\end{array}$ \\
\hline $\begin{array}{l}\text { Adanya keluhan harga alat laboratorium } \\
\text { Sub Bidang Lingkungan Hidup seperti } \\
\text { alat ukur kualitas air,kualitas udara dan } \\
\text { uji merkuri yang tidak memadai menurut } \\
\text { keinginan daerah. }\end{array}$ & $\begin{array}{l}\text { Pembelian alat-alat laboratorium dilakukan } \\
\text { daerah dengan standar biaya yang dipakai } \\
\text { tidak sesuai dengan standar harga yang } \\
\text { ditetapkan dalam menu DAK yang } \\
\text { berdampak pada kurangnya pembayaran }\end{array}$ \\
\hline $\begin{array}{l}\text { Pelaksanaan rehabilitasi hutan dan lahan } \\
\text { dengan Dana DAK tidak terlalu } \\
\text { disambut antusias oleh Pemda } \\
\text { penyelenggara DAK Fisik Penugasan } \\
\text { Sub Bidang Kehutanan }\end{array}$ & $\begin{array}{lr}\text { Standar biaya yang lebih rendah dari APBN } \\
\text { murni untuk kegiatan yang sama } \\
\text { menyebabkan keengganan } & \text { Pemda } \\
\text { merealisasikan dana DAK yang ada } & \end{array}$ \\
\hline $\begin{array}{l}\text { Sebagian daerah tidak mengalokasikan } \\
\text { APBD untuk pengelolaan sampah yang } \\
\text { menjadi masalah daerah }\end{array}$ & $\begin{array}{l}\text { Adanya ketergantungan yang tinggi dana } \\
\text { DAK untuk pengelolaan sampah khususnya } \\
\text { daur ulang didaerah }\end{array}$ \\
\hline
\end{tabular}




\begin{tabular}{l|l}
\hline $\begin{array}{l}\text { Target perbaikan IKLH didaerah tidak } \\
\text { signifikan dipengaruhi oleh dana DAK, }\end{array}$ & $\begin{array}{l}\text { Menu kegiatan alat pemantau dalam DAK } \\
\text { Fisik Penugasan Sub Bidang Lingkungan } \\
\text { khususnya DAK Fisik Penugasan Sub } \\
\text { Bidang Lingkungan Hidak menjawab akar masalah sesuai } \\
\text { sasaran RKP }\end{array}$ \\
\hline
\end{tabular}

Sumber: Hasil Analisis, 2020

\section{Rekomendasi}

Berdasarkan hasil analisis, beberapa hal masih perlu diperbaiki dari penyelenggaraan DAK Fisik Penugasan Bidang Lingkungan Hidup dan Kehutanan. Beberapa rekomendasi yang dapat diberikan antara lain: a) perlunya Kementerian PPN/Bappenas memiliki peran yang sama dengan Kementerian Keuangan dalam menetapkan alokasi anggaran DAK untuk menjamin target-target RKP tercapai dengan optimal; b) perlu peningkatan koordinasi serta peran aktif Pemda, untuk memenuhi mekanisme dan syarat pencairan DAK sesuai regulasi yang diatur oleh Pemerintah Pusat (Kemenkeu); c) perlu ada sistem pelaporan satu pintu melalui aplikasi Krisna yang dapat diakses oleh semua pelaku DAK pusat dan daerah; d) perlu disusun kerangka pengendalian dalam implementasi DAK, termasuk menghentikan pencairan jika terjadi inkonsistensi dengan perencanaan; e) perlunya menyusun sistem monitoring dan evaluasi (Monev) bersama dengan melibatkan setiap stakeholder (pusat dan daerah) dengan kewajiban pengalokasian anggaran monev dalam Juknis pada setiap tahapan perencanaan, penganggaran dan pelaksanaan DAK; f) perlu dipertimbangan perubahan menu kegiatan pengadaan alat pemantau kualitas air, udara dan lain lain karena menu kegiatan tersebut tidak dapat memperbaiki kualitas air, udara dan lain lain secara langsung (kerangka logisnya terlalu jauh); g) perlunya Kementerian LHK melalui unit pelaksana teknis didaerahnya (BPDAS-HL) menginisiasi monitoring evaluasi berkala bersama Bappeda Provinsi sekaligus sebagai upaya peningkatan koordinasi antar stakeholders; h) erlunya pelibatan Pemda secara bottom up dalam penentuan standar biaya yang dilakukan oleh $\mathrm{K} / \mathrm{L}$ teknis DAK untuk mendapatkan standar yang ideal dan berlaku universal secara nasional; serta i) perlunya peningkatan sosialisasi konsep DAK yang lebih luas oleh K/L bahwa DAK hanya stimulan pendanaan, bukan anggaran utama daerah dalam pembangunan

\section{Referensi}

Bonet, Jaime. (2006). Fiscal Decentralization and Regional Income Disparities: envidence from the Colombian experience. Article in The Annals of Regional Science 4O(3):661-676 . DOI $10.1007 /$ s00168-006-0060-Z

Brodjonegoro, Bambang. (2006). The Indonesian Decentralization after Law Revision: Toward a Better Future?', in International Conference on Responsive and Accountable Local Governance, Hotel Nikko, Jakarta, 21-22 February 2006.

Hidayat, S. (2005). Otonomi Daerah, Pilkada dan Komitmen Desentralisasi Politik: Tinjauan atas tiga UU mengenai Otonomi Daerah dalam Pilkada Langsung, Demokratisasi Daerah dan Mitos Good Governance. Jakarta: Partnership dan Pusat Kajian Ilmu Politik Fisip UI.

Hirawan, S.B. (2007). Desentralisasi Fiskal Sebagai Suatu Upaya Meningkatkan Penyediaan Layanan Publik (Bagi Orang Miskin) di Indonesia. Jakarta: UI.

Kuncoro M. (2004). Otonomi dan Pembangunan Daerah. Jakarta: Erlangga

Oates, WE. (1999). An Essay on Fiscal Federalism, Journal of Economic Literature, vol. 37, no. 3, pp. 1120-1149.

Oates, WE. (1993). Fiscal Decentralization and Economic Development, National Tax Journal, vol. 46, no. 2, pp. 237-243. 
Pemerintah Indonesia. (2018). Peraturan Presiden No. 141 Tahun 2018 tentang Petunjuk Teknis Dana Alokasi Khusus Fisik Tahun Anggaran 2019. Jakarta: Pemerintah Indonesia Pemerintah Indonesia. (2018). Peraturan Presiden Republik Indonesia Nomor 72 Tahun 2018 Tentang Rencana Kerja Pemerintah Tahun 2019. Jakarta: Pemerintah Indonesia

Pemerintah Indonesia. (2015). Peraturan Pemerintah No. 55 Tahun 2005 tentang Dana Perimbangan. Jakarta: Pemerintah Indonesia

Pemerintah Indonesia. (2006). Peraturan Pemerintah No. 39 Tahun 2006 tentang Tata Cara Pengendalian dan Evaluasi Pelaksanaan Rencana Pembangunan. Jakarta: Pemerintah Indonesia

Pemerintah Indonesia. (2004). Undang-Undang Nomor 25 Tahun 2004 tentang Sistem Perencanaan Pembangunan Nasional. Jakarta: Pemerintah Indonesia

Pemerintah Indonesia. (2004). Undang-Undang No. 33 Tahun 2004 tentang Perimbangan Keuangan antara Pemerintah Pusat dan Pemerintah Daerah. Jakarta: Pemerintah Indonesia

Setiadi H. (2009). Konsep Pusat-Pinggiran: Sebuah Tinjauan Teoritis. Fakultas Matematika dan Ilmu Pengetahuan Alam. Depok: Working Paper No. KKI-O1/KBP-PW/2009. Universitas Indonesia. 